\title{
Peran Kepemimpinan Dalam Keluarga Pada Pembelajaran Daring Di Desa Sangatta Utara
}

\author{
Ramdanil Mubarok \\ Jurusan Tarbiyah, STAI Sangatta Kutai Timur \\ email: danil.education@gmail.com
}

\begin{abstract}
Received: 04 March 2021; Revised: 26 April 2021; Accepted: 28 August 2021
DOI: http://dx.doi.org/10.37905/aksara.7.3.1251-1262.2021
\end{abstract}

\begin{abstract}
Abstrak
Pembelajaran dari rumah menegaskan perlunya orang tua sebagai pemimpin untuk melakukan peran sebagai pendamping belajar anak. Penelitian ini akan mencoba memotret bagaimana proses pelaksanaan pembelajaran daring, bagaimana peran kepemimpinan dalam keluarga pada pembelajaran daring, serta bagaimana kendala pelaksanaan pembelajaran daring. Metode kualitatif deskriptif menjadi metode yang digunakan penulis dalam penelitian ini. Penelitian dengan metode kualitatif deskriptif tersebut merupakan sebuah cara yang dilakukan untuk mengungkap fenomena yang terjadi di lapangan. Teknik pengambilan data dalam penelitian ini dengan observasi dan wawancara, sumber datanya adalah orang tua yang memiliki anak yang sedang mengenyam pendidikan di Sekolah Dasar. Sementara analisis datanya menggunakan analisis data model interaktif dengan menyajikan data, reduksi data, membuat kesimpulan, dan terakhir melakukan verifikasi data. Hasilnya adalah proses pembelajaran daring dilaksanakan dirumah dengan menggunakan aplikasi WhatsApp, Google Classroom, Google Meet, Zoom dengan tahapan-tahapan a) Persiapan: merancang rencana pembelajaran, mengkondisikan waktu, sarana belajar, serta persiapan fisik dan mentalnya. b) Pelaksanaan pembelajaran: pendahuluan, kegiatan inti, dan kegiatan penutup. Adapun peran kepemimpinan dalam keluarga antara lain: mendidik, membimbing, mengarahkan, dan memimpin keluarga. Kendala yang dihadapi dalam pendampingan belajar anak pada pembelajaran daring antara lain motivasi belajar anak yang kurang, kemampuan literasi digital, dan kemampuan bekerjasama
\end{abstract}

\section{Kata Kunci: kepemimpinan, keluarga, pembelajaran daring}

\begin{abstract}
Learning from home emphasizes the need for parents as leaders to play a role as a child's learning companion. This study will try to photograph how the process of implementing online learning is, how the role of leadership in the family in online learning is, and how the obstacles to implementing online learning are. The descriptive qualitative method is the method used by the author in this study. Research with the descriptive qualitative method is a way to uncover phenomena that occur in the field. The data collection technique in this study is by observation and interviews, the data sources are parents who have children who are currently studying in elementary schools. Meanwhile, the data
\end{abstract}


analysis uses interactive model data analysis by presenting data, reducing data, making conclusions, and finally verifying data. The result is that the online learning process is carried out at home using the WhatsApp, Google Classroom, Google Meet, Zoom applications with the stages a) Preparation: designing learning plans, conditioning time, learning facilities, as well as physical and mental preparation. b) Implementation of learning: introduction, core activities, and closing activities. The leadership roles in the family include: educating, guiding, directing, and leading the family. Obstacles faced in assisting children's learning in online learning include children's lack of motivation to learn, digital literacy skills, and the ability to work together.

\section{Keywords : leadership, family, online learning.}

\section{PENDAHULUAN}

Pandemi Covid-19 di seantero belahan dunia sekarang ini memaksa setiap individu untuk beradaptasi dengan kebiasaan-kebiasaan baru, mulai dari anjuran bekerja dari rumah, anjuran belajar dari rumah, sampai pada aktivitas privat seperti ibadah pun dilakukan dari rumah. Pemerintah sudah berkali-kali mengeluarkan surat edaran tentang bekerja dari rumah, belajar dari rumah, dan ibadah dari rumah dikarenakan pandemi Covid-19 tidak kunjung selesai. Sehingga seluruh aktivitas pembelajaran ditiadakan di sekolah hingga kegiatan-kegiatan akademik lainnya. Hal tersebut menjadi dinamika di dalam dunia pendidikan (Muhaemin, 2020). Konsekuensi logisnya adalah lembaga pendidikan harus melaksanakan pembelajaran dari rumah (Arora, Amit Kumar, 2020) sehingga dibutuhkan kesabaran, keikhlasan, dan keuletan sebagai kriteria yang harus dimiliki dalam proses belajar dari rumah (Baharun, 2018).

Aktivitas pendidikan merupakan salah satu yang terdampak dari adanya wabah virus corona ini (Saleh, 2020). Kurikulum pendidikan berubah menjadi kurikulum darurat (Astuty \& Suharto, 2021), proses pembelajaran dilakukan secara daring dari rumah (Ramanta \& Widayanti, 2020), sehingga proses pembelajaran tidak maksimal. Sehingga timbullah berbagai macam kesulitan-kesulitan baik dari anak maupun dari orang tua yang harus mendampingi anak dalam belajar. Kesulitan-kesulitan dalam pembelajaran daring menjadi dinamika yang tidak mudah untuk diatasi mulai dari jaringan internet yang tidak stabil, kesibukan orang tua dan tidak familiarnya orang tua dalam menggunakan teknologi, begitu juga dengan harga kuota internet, dan motivasi belajar anak yang kurang.

Pemberlakuan belajar dari rumah sedikit banyak akan berdampak pada aktivitas kepemimpinan di dalam keluarga. Sebagai pemimpin di dalam keluarga, orang tua harus mampu membagi waktu untuk mengontrol, membimbing, mengarahkan, dan mendampingi anak untuk belajar daring di rumah. Pro dan kontra terhadap kebijakan belajar daring dari rumah merupakan hal yang menjadi dinamika dalam prose belajar dari rumah. Hasil penelitian (Cahyati \& Kusumah, 2020) bahwa terdapat orang tua yang kontra dengan kebijakan belajar dari rumah disebabkan karena orang tua yang tidak familiar dengan teknologi. Namun menurut (Roshonah, Putri, \& Yulianingsih, 2020) bahwa pembelajaran dari rumah memiliki hal yang sangat positif dari segi kedekatan orang tua dan anak serta mampu melihat langsung perkembangan belajar anaknya. 
Pembelajaran dari rumah merupakan suatu model pembelajaran yang baru dalam dinamika pendidikan masa kini (Cahyani, Listiana, \& Larasati, 2020). Terlepas dari adanya pandemi Covid-19 sebenarnya pembelajaran yang semisal adalah pembelajaran jarak jauh yang dahulu pernah digaungkan (Muhaemin, 2020). Namun kini pembelajaran dari rumah menegaskan perlunya orang tua sebagai pemimpin di rumah untuk melakukan pengawasan dan mendampingi anak untuk belajar.

Penelitian terdahulu yang dilakukan oleh (Sahara, 2020), dalam penelitiannya menggunakan penelitian kualitatif dengan pendekatan deskriptif. Hasilnya, keterlibatan orang tua masih rendah di awal pemberlakuan belajar dari rumah, pengembangan model pelibatan dilakukan melalui perencanaan, pelaksanaan, melakukan validasi, dan menyusun model. Penelitian (Uki \& Ilham, 2020), dimana dalam penelitiannya menggunakan penelitian kuantitatif, hasil penelitiannya menyatakan bahwa belajar mandiri dengan prestasi belajar mempunyai pengaruh yang signifikan. Sementara penelitian terdahulu yang lain yaitu penelitian (Roshonah et al., 2020), dalam penelitiannya menggunakan penelitian deskriptif kualitatif dengan menggunakan angket dan menjadikan orang tua yang mempunyai anak di SDN Pisangan 01 menjadi respondennya. Hasilnya bahwa orang tua mempunyai peran yang sangat penting dalam mendampingi pembelajaran anak serta mampu melihat langsung perkembangan pembelajaran anaknya. Mayoritas responden merespon bahwa pembelajaran dari rumah dapat mendekatkan anak dengan orang tua yang selama ini renggang karena faktor kesibukan. Demikian juga dengan anaknya akan lebih fokus dalam pembelajarannya dikarenakan langsung diawasi oleh orang tuanya. Demikian juga penelitian (Cahyati \& Kusumah, 2020), dalam penelitiannya menggunakan metode kualitatif fenomenologis yang mana datanya diperoleh dari angket. Respondennya adalah orang tua yang mempunyai anak antara umur lima sampai delapan tahun. Hasil penelitiannya menyatakan bahwa pembelajaran dari rumah efektif, meningkatkan kedekatan dengan anak, dan dapat memantau langsung perkembangan kemampuan anaknya.

Penelitian ini akan mencoba memotret bagaimana proses pelaksanaan pembelajaran daring, bagaimana peran kepemimpinan dalam keluarga pada pembelajaran daring, serta bagaimana kendala pelaksanaan pembelajaran daring. Orang tua sebagai pemimpin harus mampu memainkan perannya dalam mendampingi anak-anak belajar. Tujuannya adalah untuk mendapat gambaran tentang proses pelaksanaan pembelajaran daring, peran kepemimpinan dalam keluarga pada pembelajaran daring, serta mengetahui kendala pelaksanaan pembelajaran daring. Penelitian ini diharapkan mampu memberikan masukan bagi orang tua dalam pembelajaran daring di tengah kondisi yang begitu banyak pembatasan-pembatasan dalam aktivitas keseharian terutama di bidang pendidikan.

\section{METODE}

Metode kualitatif deskriptif menjadi metode yang digunakan penulis dalam penelitian ini. Penelitian dengan metode kualitatif deskriptif tersebut merupakan sebuah cara yang dilakukan untuk mengungkap fenomena yang terjadi di lapangan, Fenomenologis merupakan penelitian yang secara khusus melihat fenomena yang akan diteliti, fokus pada subjek penelitian, memaparkan permasalahan, memaparkan dan menganalisis data, dan mencari data dengan observasi langsung (Rukin, 2019). Teknik 
pengambilan data menggunakan observasi dan wawancara, sumber datanya adalah orang tua yang memiliki anak yang sedang mengenyam pendidikan di Sekolah Dasar. Sementara analisis datanya menggunakan analisis data model interaktif dengan menyajikan data, reduksi data, membuat kesimpulan, dan terakhir melakukan verifikasi data. Penelitian ini berlangsung selama tiga bulan yaitu dari bulan Maret sampai bulan April di Desa Sangatta Utara, Kabupaten Kutai Timur.

\section{HASIL DAN PEMBAHASAN}

Hasil oservasi dan wawancara yang dilakukan penulis pada orang tua yang mempunyai anak yang sekolah di jenjang sekolah dasar di desa Sangat Utara bahwa para orang tua telah melakukan pendampingan terhadap pembelajaran daring anak di rumah. Pendampingan belajar anak dilakukan dengan berbagai macam cara, ada yang menggunakan ancaman, ada yang menggunakan hadiah, ada yang mendampingi pembelajaran anak dengan cara duduk disamping anaknya, dan ada juga yang mendampingi pembelajaran anak dengan paruh waktu (Observasi, 9 Maret 2021).

Bapak Abdullah misalnya, ia merupakan seorang ASN yang harus bekerja di pagi hari dan pulang di sore hari, maka ia akan mendampingi anak-anak dengan mengontrol dari kantor melalui telepon untuk sekedar memotivasi anak dan memberikan perhatian ketika pembelajaran daring (Wawancara, 11 April 20201). Lain lagi dengan bapak Anami yang merupakan seorang doja Masjid, ia akan mendampingi pembelajaran daring anak secara intensif karena kesibukan sebagai doja hanya pada saat-saat pelaksanaan shalat (Wawancara, 21 April 2021). Berbeda dengan Pak Solihin yang merupakan karyawan perusahaan, ia menyerahkan sepenuhnya pendampingan pembelajaran anak pada istrinya yang merupakan seorang ibu rumah tangga (Wawancara, 30 April 2021).

Kendala yang dihadapi para orang tua juga bermacam-macam, wawancara dengan bapak Yunus misalnya, kesulitan yang dihadapi dalam mendampingi pembelajaran daring anak terletak pada kurang mampunya untuk mengoperasikan teknologi dan kurangnya komunikasi dengan guru (Wawancara, 5 Mei 2021), lain lagi dengan ibu Sri yang merupakan ibu rumah tangga yang pernah kuliah jurusan informatika, ia tidak akan kesulitan dalam hal teknologi namun kesulitan dalam mendampingi anak belajar daring karena kurang termotivasinya anak untuk belajar hal tersebut dikarenakan anaknya yang merupakan siswa baru menginginkan pergi ke sekolah untuk bertemu dengan guru dan teman kelasnya serta menginginkan belajar di sekolah barunya (Wawancara 15 Mei 2021).

\section{Proses Pelaksanaan Pembelajaran Daring}

Berdasarkan hasil observasi dan wawancara diatas maka pembelajaran daring yang dilakukan anak di rumah memang membutuhkan pendampingan oleh orang tua karena disamping anak sekolah dasar yang masih kecil orang tua juga harus mengawasi anak dalam penggunaan teknologi internet. Karena dalam teknologi internet tidak terdapat begitu banyak konten yang tidak sesuai dengan usia anak sekolah dasar.

Pembelajaran daring yang berlaku sekarang pada dasarnya hanya untuk membatasi kegiatan yang dilakukan masyarakat sehingga tidak terjadi kerumunan yang berpotensi menularkan virus. Pembelajaran daring merupakan pembelajaran yang 
AKSARA: Jurnal Ilmu Pendidikan Nonformal

P-ISSN 2407-8018 E-ISSN 2721-7310 DOI prefix 10.37905

Volume 07, (03) September 2021

http://ejurnal.pps.ung.ac.id/index.php/Aksara

berbasis teknologi yang memiliki pengaruh yang sangat signifikan. Teknologi ini kemudian dimanfaatkan untuk untuk keberlangsungan proses belajar mengajar dari cara tatap muka (tradisional) ke cara belajar modern (online). Dengan berkembangnya teknologi maka pembelajaran juga berkembang. Hasil penelitian yang mengatakan bahwa teknologi memberikan pengaruh yang positif terhadap pembelajaran (Priyatna, 2013). Teknologi internet menjadi sebuah sarana/media pembelajaran pada masa pandemi Covid-19 (Astuti, Dasmo, \& Sumarni, 2018) yang dipadukan dengan kreativitas guru.

Pembelajaran daring merupakan pembelajaran yang dilakukan di tempat yang berbeda tanpa adanya tatap muka namun menggunakan berbagai macam aplikasi dalam proses pembelajaran. Poin pentingnya adalah proses pembelajaran yang tidak terikat dengan tempat yang spesifik, karena antara guru dan murid melakukan proses pembelajaran di tempat yang tidak menentu. Pandemi Covid-19 di desa Sangatta Utara sangat terasa bagi para orang tua yang mempunyai anak yang sekolah di sekolah dasar. Dengan adanya pandemi Covid-19 ini maka secara otomatis maka kegiatan-kegiatan yang berpotensi mengundang kerumunan ditiadakan termasuk kegiatan belajar mengajar di sekolah. Keadaan inilah yang memaksa para siswa untuk melaksanakan pembelajaran dari rumah. Keadaan yang demikian merupakan suatu keadaan yang baru bagi siswa karena harus belajar dengan mengandalkan teknologi dengan berbagai macam platformnya, mulai dari menggunakan aplikasi aplikasi WhatsApp, Google Classroom, Google Meet, Zoom (Ma'ruufah, Gestiardi, \& Chumdari, 2021), dan berbagai bentuk aplikasi lainnya. Pembelajaran daring ini adalah model pembelajaran yang baru bagi guru, anak, dan bahkan orang tua yang mendampingi proses belajar anak. Pada proses pembelajaran daring seorang guru mempunyai kewajiban untuk membuat perencanaan pembelajaran yang efektif dan efisien kemudian digunakan dalam pembelajaran daring melalui jaringan internet.

Pembelajaran daring yang dilakukan di rumah harus harus dilakukan dengan persiapan yang matang dengan tahapan-tahapan yang detail sehingga tidak terkesan hanya memenuhi kewajiban hadir di aplikasi bagi anak, dan menggugurkan kewajiban bagi guru. maka langkah-langkah yang perlu dipersiapkan antara lain :

Langkah pertama adalah dengan melakukan persiapan. Persiapan harus dilakukan oleh guru, orang tua, dan anak supaya pembelajaran daring berjalan dengan baik. Guru melakukan persiapan dengan merancang rencana pembelajaran, orang tua melakukan persiapan dengan mengkondisikan waktu dan pekerjaannya serta sarana belajar pada saat pembelajaran berlangsung, serta anak-anak harus dipersiapkan fisik dan mentalnya sehingga bisa menerima materi dengan baik.

Langkah pelaksanaan pembelajaran. Langkah kedua ini memang lebih condong dilakukan oleh para guru namun orang tua yang mendampingi anak belajar juga perlu terlibat aktif dalam pelaksanaan pembelajaran daring. Umumnya dalam pelaksanaan pembelajaran maka ada kegiatan pendahuluan, kegiatan inti, dan kegiatan penutup. Semua langkah yang disebutkan diatas seharusnya sudah tertuang di dalam rencana pembelajaran yang dibuat oleh guru, dan orang tua yang mendampingi anak dalam pembelajaran daring seharus mendapatkan salinan rencana pembelajaran tersebut sehingga pendampingan yang dilakukan oleh orang tua menjadi maksimal. Dengan 
demikian maka pembelajaran daring tak ubahnya pembelajaran yang dilakukan di dalam ruang kelas karena pelaksanaannya yang sesuai dengan rencana pembelajaran namun yang menjadi pembeda adalah pembelajaran tersebut dilakukan di dalam jaringan (daring) tanpa mengubah jadwal belajar, rencana pembelajaran, metode pembelajaran, materi pembelajaran dan tata tertib.

\section{Peran Kepemimpinan Keluarga dalam Mendampingi Pembelajaran Anak}

Setiap pemimpin dalam keluarga memiliki cara yang berbeda dalam mendidik, membimbing, mengarahkan, dan memimpin anaknya dalam keluarga. Secara umum kepemimpinan orang tua terdiri dari tiga macam yaitu kepemimpinan demokratis, otoriter, dan liberal. Kepemimpinan merupakan kemampuan seseorang yang telah ada dan melekat pada diri seseorang (Ifendi, 2020) Dan setiap individu yang mempunyai tanggung jawab adalah seorang pemimpin (Siddeh, 2021). Setiap manusia mempunyai peran dan tugas yang terprogram pada diri masing-masing sehingga setiap orang bisa menjadi pemimpin (Yuminah, 2018). Dalam kategori apapun seorang pemimpin harus amanah, seperti amanah dalam kepemimpinannya, amanah dalam jabatannya, amanah dalam pekerjaan sehingga amanah tersebut terlaksana dengan baik (Halim, Zulheldi, \& Sobhan, 2019)

Maka kepemimpinan orang tua dalam keluarga merupakan bentuk tanggung jawab untuk mendidik, membimbing, mengarahkan, dan memimpin anaknya dengan gaya kepemimpinan demokratis, otoriter, dan liberal guna mendampingi anak dalam pembelajaran daring. Kepemimpinan merupakan kategori ilmu terapan yang diharapkan dapat mendatangkan manfaat bagi keberlangsungan kehidupan manusia. Jadi yang dimaksud dengan pemimpin disini adalah ayah karena di pundaknya lah harapan dan citacita keluarga dibebankan. Ayah merupakan sosok kepala keluarga yang merencanakan, mengatur, dan mengevaluasi segala sesuatu yang berkaitan dengan keberlangsungan kehidupan keluarga. Seorang ayah sebagai seorang pemimpin di dalam keluarga harus memiliki sifat kepemimpinan yang baik. Seorang ayah harus menduplikasi sifat-sifat kepemimpinan Rasulullah yaitu siddiq, amanah, fatonah. tabligh (Rohimah, Atqiyya, \& Maharani, 2021).

Seorang ayah sebagai pemimpin di dalam keluarga harus siddiq yaitu bersifat jujur. Jujur dalam perbuatan maupun jujur dalam perkataan, karena seorang pemimpin itu merupakan teladan yang akan diikuti gerak geriknya oleh orang yang dipimpin, dalam hal ini anak dan istri. Ia juga harus mengedepankan sifat amanah yaitu dapat dipercaya, apabila seorang ayah sudah mendapatkan kepercayaan maka ia harus menjaga kepercayaan itu. Demikian juga dengan sifat fathonah yaitu cerdas, seorang pemimpin harus cerdas karena pemikirannya akan sangat dibutuhkan dalam segala hal demi tercapainya tujuan yang telah ditetapkan dalam keluarga. Dan yang terakhir adalah tabligh yaitu menyampaikan. Pemimpin harus mampu menyampaikan yang benar itu benar dan yang salah itu salah. Bentuk penyampaian dalam keluarga yang bisa dilakukan oleh seorang pemimpin adalah dengan lisan maupun dengan perbuatan.

Kepemimpinan bisa menghasilkan sesuatu yang positif dan sebaliknya juga kepemimpinan bisa menghasilkan sesuatu yang negatif, dan buah dari kepemimpinan tersebut tergantung dari bagaimana cara dia menerapkan sifat siddiq, amanah, fatonah. tablig. Seorang pemimpin dalam keluarga harus mampu membimbing dan mempengaruhi 
anggota keluarga yang dipimpin. Secara umum gambaran akan kepemimpinan orang tua siswa yang berdomisili di desa Sangatta Utara menerapkan gaya kepemimpinan yang otoriter. Adapun efek dari gaya kepemimpinan otoriter adalah turunnya prestasi belajar anak sehingga perlu diadakannya evaluasi.

Orang tua sebagai pemimpin harus menerapkan gaya kepemimpinan yang baik dan tepat demi menunjang aktivitas belajar peserta didik sehingga berpengaruh pada motivasi belajar mandiri anaknya. Begitupun sebaliknya orang tua sebagai pemimpin yang tidak memperhatikan pendidikan dan motivasi belajar mandiri anaknya seperti acuh terhadap anaknya. Berbagai macam bentuk kepemimpinan yang dapat dilakukan oleh orang tua dalam keluarga antara lain :

\section{Kepemimpinan yang demokratis}

Kaitannya dengan kepemimpinan demokratis maka kepemimpinan beberapa orang tua di desa Sangat Utara telah menerapkannya. Salah satunya adalah Bapak Syam, beliau memimpin keluarga dengan menggunakan gaya kepemimpinan demokratis dimana dengan model kepemimpinan tersebut ia menunjukkan perhatian dan kasih sayang sepenuhnya. Ia juga ikut berpartisipasi dalam kegiatan belajar anak, dan memberikan kepercayaan penuh kepada anak. Ia selalu memberikan nasehat dan dorongan kepada anak untuk selalu belajar demi meraih cita-cita yang telah dipilih. Dalam menentukan sesuatu hal selalu melibatkan anak untuk memberikan pendapat sehingga anak merasa dihargai keberadaanya. Hal tersebut penting untuk dilakukan sehingga anak akan termotivasi untuk belajar secara mandiri karena tidak adanya keterpaksaan dari seorang ayah yang menjadi pemimpin di dalam keluarga.

\section{Kepemimpinan Otoriter}

Salah satu orang tua yang menggunakan gaya kepemimpinan otoriter adalah bapak Faris. Dalam prakteknya ia menuntut anaknya untuk patuh secara mutlak tanpa harus membatasi apa yang menjadi peraturan dan tata tertib yang telah dibuat. Dalam kepemimpinan otoriter tersebut seorang ayah tidak memberikan ruang kepada anak untuk mengutarakan kemauan anak. Akibatnya anak akan selalu merasa tertekan dan tidak nyaman karena selalu dihantui dengan hukuman ketika melanggar aturan-aturan yang telah ditetapkan. Di satu sisi model kepemimpinan seperti ini baik demi masa depan anak yang cerah karena telah ditanamkan dalam diri seorang anak akan kedisiplinan, tata krama, dan patuh kepada orang tua.

\section{Kepemimpinan Liberal}

Kepemimpinan model ini terjadi pada bapak Man yang tidak mampu mengendalikan anaknya, disiplin di dalam keluarganya lemah dan tidak konsisten. Anak akan dibiarkan mengikuti aturan-aturan rumah, namun tidak akan ditegur ketika melanggar aturan rumah. Kepemimpinan model ini memberikan tanggung jawab penuh kepada anak untuk memilih jalan hidupnya, memberikan kekuasaan penuh kepada anaknya, demikian juga dalam hal pendidikan.

Peran penting orang tua dalam mendampingi anak belajar daring sangat besar karena anak-anak merupakan aset yang sangat berharga. Peran kepemimpinan keluarga dalam pembelajaran daring maupun luring tetap sama-sama penting karena tidak bisa dipungkiri bahwa seorang anak sekolah dasar tidak bisa lepas dari peran orang tuanya. 
Orang tua bisa menjadi guru bagi anak-anaknya dan bahkan bisa menjadi teman dalam situasi yang lain.

Peran kepemimpinan keluarga dalam mendampingi pembelajaran anak pada pembelajaran daring akan sangat penting dan efektif apabila orang tua mampu mengamati mata pelajaran, metode, dan faktor pendukung (Priyatna, 2013, p. 4). Maka langkah penting dalam mendampingi pembelajaran daring anak adalah mengamati dengan seksama mata pelajaran yang akan dipelajari. Orang tua harus mengontrol dan mengetahui jadwal pelajaran anak setiap hari sehingga orang tua bisa mengkondisikan diri untuk tetap bisa mendampingi anak dalam pembelajaran daring. Kemudian orang tua juga harus melihat dan berusaha mengamati bagaimana metode pembelajaran yang efektif dalam pembelajaran daring sehingga bisa melakukan penguatan pembelajaran diluar jadwal yang telah ditentukan dari sekolah. Terakhir orang tua mengamati faktor pendukung yang dapat mengefektifkan pembelajaran daring anak di rumah. Orang tua bisa mempertimbangkan alternatif-alternatif lain dalam membantu anak-anak untuk mencapai kompetensi dalam sebuah mata pelajaran, baik dengan guru les atau dengan mengintensifkan pembelajaran dirumah diluar jam pembelajaran daring.

\section{Kendala Pendampingan Pembelajaran Anak}

Fenomena adanya wabah Covid-19 ini sangat berdampak ke semua lini dalam kehidupan masyarakat, tidak terkecuali pada bidang pendidikan. Penting bagi masyarakat desa Sangat Utara untuk ikut berperan aktif dalam melaksanakan anjuran pemerintah tentang social distancing serta mensosialisasikannya guna meringankan tugas pemerintah. Ada unsur keterpaksaan pada diri siswa untuk belajar dari rumah karena di lain sisi para siswa tidak lagi dapat bertemu dengan teman-temannya, tidak dapat lagi melakukan interaksi langsung dengan temannya, bahkan dengan gurunya. Akibat dari pembelajaran daring ini dapat mempengaruhi motivasi belajar siswa karena para siswa akan merasa jenuh, dan tidak termotivasi untuk belajar secara mandiri. Yang terjadi kemudian adalah kurang optimalnya guru dalam mengajar, membimbing, mengawasi, dan mengevaluasi siswa dalam kegiatan belajar mengajar karena keterbatasan ruang dan waktu.

Keadaan para orang tua yang sibuk bekerja sebagai aparatur sipil negara (ASN) atau sebagai karyawan perusahaan maupun swasta menambah panjang permasalahan orang tua untuk dapat memotivasi belajar mandiri anak selama pandemi Covid-19. Terdapat beberapa anak yang yang memiliki kedua orang tuanya yang bekerja, dan sebagian yang lain satu di antara ayah atau ibu yang bekerja. Diantara kesulitankesulitan yang dihadapi dalam pendampingan belajar anak pada pembelajaran daring antara lain sebagai berikut:

\section{Motivasi Belajar Anak yang kurang}

Seseorang dikatakan termotivasi apabila dalam dirinya terdapat dorongan energi dalam dirinya, adanya perasaan dalam dirinya, serta adanya reaksi untuk mencapai tujuan (Hamalik, 2013, p. 121). Untuk memahami motivasi maka perlu suatu pendekatan dalam mengimplementasikannya karena motivasi merupakan sebuah proses dan motivasi merupakan sebuah petunjuk. Sedangkan belajar merupakan perubahan 
yang bersifat internal yang diwujudkan dalam perbuatan baik berupa pengalaman maupun latihan yang menyangkut aspek kepribadian fisik (Setiawan, 2017, p. 2). Teori lain mengatakan bahwa belajar merupakan suatu perubahan tingkah laku seseorang berdasarkan praktik tertentu guna menghasilkan interaksi dengan lingkungan dan sumber belajar disekitarnya (Suyono \& Hariyanto, 2014, p. 9).

Jadi motivasi belajar mandiri merupakan kesadaran yang berasal dari dalam diri seseorang untuk belajar guna mencapai tujuan tanpa ada paksaan. Sehingga seorang siswa akan melakukan aktivitas belajar tanpa diperintah oleh orang tua atau tanpa ada iming-iming lain. Ketika kesadaran tersebut sudah ditanamkan dalam diri seorang siswa maka dimanapun dan kapanpun, diawasi maupun diawasi, proses pembelajaran akan terus dilaksanakan dikarenakan adanya kesadaran dan tujuan dalam diri siswa yang ingin dicapai.

\section{Kemampuan Literasi Digital}

Kemampuan literasi digital ini menjadi salah satu kendala dalam pembelajaran daring dikarenakan tidak semua anak maupun orang tua mampu untuk memanfaatkan teknologi dan perpustakaan-perpustakaan digital untuk menunjang pembelajaran anak. Disaat yang sama perpustakaan digital merupakan penunjang utama dan sebagai sumber belajar (Mubarok, 2021) anak dalam pembelajaran daring di masa pandemi Covid-19.

\section{Kemampuan Bekerjasama}

Kemampuan bekerjasama juga termasuk salah satu kendala dan kesulitan dalam pembelajaran daring hal tersebut terjadi karena kesibukan orang tua, atau tingkat emosional orang tua yang terkadang membuat suasana belajar daring tidak kondusif. Begitu pula kemampuan kerjasama antara orang tua dengan guru, dalam pembelajaran daring penting bagi orang tua untuk membangun kerjasama. Orang tua dan guru harus bekerjasama dalam proses pembelajaran daring (Fortuna \& Fitria, 2021) untuk mencapai kompetensi yang telah direncanakan. Bukan hanya kemampuan kerjasama anak dan orang tua atau antara orang tua dengan guru, bahkan antara anak dengan teman sekolahnya juga perlu adanya kerjasama untuk memudahkan pembelajaran daring.

Kesulitan kesulitan di atas memang tidak seluruhnya didapat dalam sebuah keluarga, namun pada umumnya realita tersebut terjadi pada orang tua yang mempunyai anak yang duduk di bangku sekolah dasar. Terkait kesulitan-kesulitan tersebut memang menjadi hal yang harus dijalani oleh orang tua dalam mendampingi pembelajaran anak, karena salah satu upaya dalam menekan laju penyebaran Covid-19 adalah menjaga jarak menghindari kerumunan. Namun kesulitan-kesulitan tersebut dapat diminimalisir apabila orang tua intens mendampingi anak-anak untuk belajar sehingaa motivasi belajarnya terjaga, kemampuan literasinya meningkat dan kerjasamnya terjalin.

\section{KESIMPULAN}

Kesimpulannya adalah bahwa pembelajaran daring dilakukan di rumah dengan menggunakan aplikasi Zoom, Google Meet, Google Classroom, WhatsApp dengan tahapan-tahapan, melakukan persiapan dengan merancang rencana pembelajaran, mengkondisikan waktu dan pekerjaannya, sarana belajar, serta persiapan fisik dan 
mentalnya. Selanjutnya dalam pelaksanaan pembelajaran ada kegiatan pendahuluan, kegiatan inti, dan kegiatan penutup. Kepemimpinan orang tua dalam bentuk mendidik, membimbing, mengarahkan, dan memimpin anaknya dengan gaya kepemimpinan demokratis, otoriter, dan liberal. Kendala yang dihadapi dalam pendampingan belajar anak pada pembelajaran daring antara lain motivasi belajar anak yang kurang, kemampuan literasi digital, dan kemampuan bekerjasama.

\section{DAFTAR PUSTAKA}

Arora, Amit Kumar, S. (2020). The impact of Pandemic COVID-19 on the TeachingLearning Process: A Study of Higher Education Teachers. Prabandhan: Indian Journal of Management, 13(4), 214-222.

Astuti, I. A. D., Dasmo, D., \& Sumarni, R. A. (2018). Pengembangan Media Pembelajaran Berbasis Android dengan Menggunakan Aplikasi Appypie di SMK Bina Mandiri Depok. Jurnal Pengabdian Kepada Masyarakat, 24(2), 695-701.

Astuty, W., \& Suharto, A. W. B. (2021). Desain Perencanaan Pelaksanaan Pembelajaran Pendidikan Agama Islam Daring dengan Kurikulum Darurat. Jurnal Penelitian Pendidikan Islam, 9(1), 81-96.

Baharun, H. (2018). Peningkatan kompetensi guru melalui sistem kepemimpinan kepala madrasah. At-Tajdid: Jurnal Ilmu Tarbiyah, 6(1), 1-26.

Cahyani, A., Listiana, I. D., \& Larasati, S. P. D. (2020). Motivasi Belajar Siswa SMA pada Pembelajaran Daring di Masa Pandemi Covid-19. IQ (Ilmu Al-Qur'an): Jurnal Pendidikan Islam, 3(01), 123-140.

Cahyati, N., \& Kusumah, R. (2020). Peran Orang Tua Dalam Menerapkan Pembelajaran Di Rumah Saat Pandemi Covid 19. Jurnal Golden Age , 4(01), 152-159.

Fortuna, R. A., \& Fitria, Y. (2021). Upaya Meningkatkan Literasi Sains Siswa Sekolah Dasar dalam Pembelajaran Daring Akibat Covid-19. Jurnal Basicedu, 5(4), 20542061.

Halim, A., Zulheldi, Z., \& Sobhan, S. (2019). Karakteristik Pemegang Amânah Dalam Al-Qur'an. Mashdar: Jurnal Studi Al-Qur'an Dan Hadis, 1(2), 185-198. https://doi.org/10.15548/mashdar.v1i2.919

Hamalik, O. (2013). Kurikulum dan Pembelajaran. Jakarta: Bumi Aksara.

Ifendi, M. (2020). Pesantren dan Kepemimpinan Kiai: Studi Kasus di Pondok Pesantren Mambaus Sholihin Gresik (1980-2020). MUDIR : Jurnal Manajemen Pendidikan, 2(2), 13-30. Retrieved from http://ejournal.insud.ac.id/index.php/mpi/index

Ma'ruufah, M. A., Gestiardi, R., \& Chumdari, M. (2021). Pemanfaatan Teknologi Dalam Pembelajaran Daring Era Covid-19 Pada Peserta Didik Kelas V Sekolah Dasar. JURNAL NALAR PENDIDIKAN, 9(1), 36-42.

Mubarok, R. (2021). Perpustakaan Digital Sebagai Penunjang Pembelajaran Jarak Jauh. Al-Rabwah, 15(01). Retrieved from http://156.67.220.215/index.php/alrabwah/article/view/72 
AKSARA: Jurnal Ilmu Pendidikan Nonformal

P-ISSN 2407-8018 E-ISSN 2721-7310 DOI prefix 10.37905

Volume 07, (03) September 2021

http://ejurnal.pps.ung.ac.id/index.php/Aksara

Muhaemin, R. M. (2020). Upgrade Kompetensi Guru PAI Dalam Merespon Pembelajaran Jarak Jauh Dimasa Pandemi Covid-19. AL-FIKR: Jurnal Pendidikan Islam, 6(2), 75-82. Retrieved from https://doi.org/10.32489/alfikr.v6i2.80

Priyatna, A. (2013). Pahami Gaya Belajar Anak! Memaksimalkan Potensi Anak dengan Modifikasi gaya Belajar. Jakarta: PT. Elex Media Komputindo.

Ramanta, D., \& Widayanti, F. D. (2020). Pembelajaran daring di sekolah menengah kejuruan putra indonesia malang pada masa pandemi covid-19. Prosiding Seminar Bimbingan Dan Konseling, 61-67.

Rohimah, R. B., Atqiyya, P. Y., \& Maharani, D. (2021). Peran Masyarakat Dalam Membentuk Karakter Kepemimpinan Islam. Jurnal Pendidikan Karakter JAWARA (Jujur, Adil, Wibawa, Amanah, Religius, Akuntabel), 7(1), 1-12.

Roshonah, A. F., Putri, S. A. D., \& Yulianingsih, I. (2020). Peran Orang Tua dalam Membimbing Anak Selama Pembelajaran Daring di Rumah. Prosiding Seminar Nasional Penelitian LPPM UMJ, 1(1).

Rukin. (2019). Metodologi Penelitian Kualitatif. Takalar: Yayasan Ahmar Cendekia Indonesia.

Sahara, L. O. (2020). Pengembangan Model Pelibatan Orang Tua Dalam Meningkatkan Kreativitas Anak melalui Pentas Kelas Pada Satuan PAUD di Kabupaten Gorontalo. Aksara: Jurnal Ilmu Pendidikan Nonformal, 06(01), 35-44.

Saleh, M. (2020). Merdeka Belajar di Tengah Pandemi Covid-19. Prosiding Seminar Nasional Hardiknas, 1, 51-56.

Setiawan, M. A. (2017). Belajar dan pembelajaran. Ponorogo: Uwais Inspirasi Indonesia.

Siddeh, K. A. (2021). Keadilan Dalam Perspektif Hadis: Analisis Teks Hadis Tentang Keadilan Seorang Pemimpin. Al-Bayan: Jurnal Ilmu Al-Qur'an Dan Hadist, 4(2), 174-186. Retrieved from https://doi.org/10.35132/albayan.v4i2.129

Suyono \& Hariyanto. (2014). Belajar dan Pembelajaran Teori dan Konsep Dasar. Bandung: PT Remaja Rosdakarya.

Uki, F., \& Ilham, A. (2020). Pengaruh Kemandirian Belajar Siswa Terhadap Prestasi Belajar di SDN 03 Limboto Barat Kabupaten Gorontalo. Aksara: Jurnal Ilmu Pendidikan Nonformal, 6(1), 89-95.

Yuminah, R. (2018). Kepemimpinan Perempuan dalam Islam. Syariah: Jurnal Hukum Dan Pemikiran, 17(1). 